九州大学学術情報リポジトリ

Kyushu University Institutional Repository

\title{
Mineralogical and Chemical Properties and Lability of Cadmium in some Soils from Japan and Vietnam
}

Huy, Trinh Quang

Graduate School of Bioresource and Bioenvironmental Sciences, Kyushu Unviersity

Matsumoto, Satoshi

Akita Prefectural University

Wada, Shin-Ichiro

Faculty of Agriculture, Kyushu Unviersity

https://doi.org/10.5109/4693

出版情報: 九州大学大学院農学研究院紀要. 50 (2)，pp.851-860，2005-10-01. Faculty of Agriculture, Kyushu University

バージョン :

権利関係 : 


\title{
Mineralogical and Chemical Properties and Lability of Cadmium in some Soils from Japan and Vietnam
}

\author{
Trinh Quang HUY', Satoshi MATSUMOTO ${ }^{2}$ \\ and Shin-Ichiro WADA ${ }^{3 *}$ \\ Laboratory of Soil Science, Division of Soil Science and Plant Production, \\ Department of Plant Resources, Faculty of Agriculture, \\ Kyushu University, Fukuoka 812-8581, Japan \\ (Received June 30, 2005 and accepted July 26, 2005)
}

\begin{abstract}
We collected five Japanese and six Vietnamese soil samples that were polluted with cadmium (Cd) and analyzed them for chemical and mineralogical properties as well as for extractability of $\mathrm{Cd}$ in water, $0.01 \mathrm{~mol} \mathrm{~L}^{-1} \mathrm{CaCl}_{2}, 0.1$ and $6 \mathrm{~mol} \mathrm{~L}^{-1} \mathrm{HCl}$. The total Cd content was in a range from 3 to $16 \mathrm{mg} \mathrm{kg}^{-1}$ for the Japanese samples and 0.5 to $1.1 \mathrm{mg} \mathrm{kg}^{-1}$ for Vietnamese samples. The soil samples had mixed clay mineralogy containing both the 1:1 and 2:1 type layer silicate minerals. We noticed no simple relationships among the mode of extractability in four different solutions and soil properties including clay mineralogy. The only exception was the relationship between the effective cation exchange capacity (ECEC) and the extractability for the Japanese samples. The regression analyses suggested that more $\mathrm{Cd}$ tends to reside on cation exchange sites of layer silicate minerals as ECEC increases but it does not results in increase of the extractability in the dilute $\mathrm{CaCl}_{2}$ solution.
\end{abstract}

\section{INTRODUCTION}

High levels of trace metals content are found in many soils and vegetations in areas affected by mining and agricultural activities, emission from metallurgical factories and automobiles. Accurate measurements of the trace metal contents in contaminated soils are important to assess the potential risk of these areas and to select remediation methods. However, total concentration is not a good indicator for metal mobility or bioavailability in soil ecosystems. The measurement of lability or bioavailability of trace metals in soils plays an important role in assessing risks and taking countermeasures to prevent ingestion by plants and animals via food webs (Ross, 1994).

A widely used method for evaluation of bioavailability of heavy metals in soils is the leaching with chemicals, such as weak acids, neutral salts, and chelating agents (Martens, 1968, Lindsay and Norwell, 1978; Haq et al., 1980; Mehlich, 1984; Singh and Narwal, 1984). Both single and sequential extraction procedures have been employed (Beckett, 1989). Although, the sequential extraction provides some useful information about the chemical forms of heavy metals, such as exchangeable, carbonated, oxide-bound and

1 Laboratory of Soil Science, Division of Soil Science and Plant Production, Department of Plant Resources, Graduate School of Bioresources and Bioenvironmental Sciences, Kyushu University

2 Faculty of Bioresource Sciences, Akita Prefectural University, Akita 010-0195, Japan

${ }^{3}$ Laboratory of Soil Science, Division of Soil Science and Plant Production, Department of Plant Resources, Faculty of Agriculture, Kyushu University

* Corresponding author (E-mail: wadasi@agr.kyushu-u.ac.jp) 
organically-bound (Tessier et al., 1979), the procedures are generally tedious and time consuming. The single extraction is more convenient, but the information from it is not satisfactory for evaluating bioavailability of metals.

In the present study, a simple sequential extraction method was devised and applied to characterize the lability of cadmium (Cd) in some polluted soils from Japan and Vietnam. The soils were also analyzed for basic properties including clay mineralogy. The results of the sequential extraction was examined in search of any relationship among the mode of distribution of $\mathrm{Cd}$ in various chemical forms and soil properties. If such relationships are present, one can broadly estimate the lability of $\mathrm{Cd}$ in a soil from the total Cd content and soil properties, which is available from databases in soil survey institutions.

\section{MATERIALS AND METHODS}

\section{Soil samples}

Cadmium-contaminated surface soil samples were taken from a $0-10 \mathrm{~cm}$ layer of arable lands in Japan and Vietnam (Table 1). The Omuta samples had been received air-born dust containing Cd salts from a neighboring smelting plant. The Kyowa and Kadzuno samples were contaminated by the tailing from metal smelting works located at upstream of the river from which irrigation water was taken. These samples were collected in Japan.

The Thanhtri, Gialam and Donganh samples were collected in the Red river delta in northern part of Vietnam. These soils were contaminated with cadmium mostly through irrigation. The sources of cadmium in the irrigation water were the manufacturers of dry cell, clock and paint, etc. In addition, the application of sediment that was dredged up from the irrigation canal may have contributed the pollution (Huy and Wada, 2004).

Table 1. Selected properties of soil samples.

\begin{tabular}{|c|c|c|c|c|c|c|c|c|c|c|c|c|}
\hline \multirow[t]{2}{*}{$\begin{array}{l}\text { Sample } \\
\text { name }\end{array}$} & \multirow[t]{2}{*}{$\mathrm{pH}$} & \multirow{2}{*}{$\begin{array}{l}\mathrm{TOC} \\
\mathrm{g} \mathrm{kg}^{-1}\end{array}$} & \multicolumn{3}{|c|}{ Exchangealbe cations } & \multirow{2}{*}{\multicolumn{2}{|c|}{$\begin{array}{c}\text { ECEC } \\
\mathrm{kg})\left(\mathrm{cmol}_{\mathrm{c}} \mathrm{kg}\right) \\
\mathrm{K}\end{array}$}} & \multirow{2}{*}{$\frac{\text { Total Cd }}{\mathrm{mg} / \mathrm{kg}}$} & \multicolumn{4}{|c|}{$\begin{array}{l}\text { Particle size distribution } \\
\qquad \mathrm{g} \mathrm{kg}^{-1}\end{array}$} \\
\hline & & & $\mathrm{Ca}$ & $\mathrm{Mg}$ & $\mathrm{Na}$ & & & & Clay & Slit & Sand & $>2 \mathrm{~mm}$ \\
\hline Omuta-1 & 5.81 & 25.7 & 7.05 & 2.15 & 2.15 & 1.51 & 12.87 & 16.27 & 275 & 318 & 310 & 98 \\
\hline Omuta-2 & 5.73 & & 4.20 & 1.01 & 0.52 & 0.55 & 6.28 & 7.95 & 256 & 285 & 351 & 108 \\
\hline Hakuba & 5.50 & 67.4 & 2.10 & 1.18 & 0.11 & 0.54 & 3.93 & 3.06 & 151 & 248 & 321 & 279 \\
\hline Kyowa & 5.59 & 69.7 & 4.12 & 0.94 & 0.26 & 0.87 & 6.19 & 6.55 & 316 & 234 & 213 & 237 \\
\hline Kadzuno & 5.82 & 106.5 & 3.36 & 0.96 & 0.25 & 1.03 & 5.60 & 3.40 & 122 & 187 & 249 & 441 \\
\hline Donganh-1 & 6.71 & 16.1 & 1.47 & 0.52 & 0.15 & 0.46 & 2.61 & 0.77 & 86 & 142 & 722 & 50 \\
\hline Donganh-2 & 8.60 & 37.3 & 10.51 & 0.86 & 0.14 & 0.42 & 11.94 & 0.82 & 108 & 129 & 416 & 348 \\
\hline Donganh-3 & 6.16 & 77.5 & 2.77 & 0.85 & 0.17 & 0.33 & 4.12 & 0.52 & 234 & 272 & 418 & 76 \\
\hline Thanhtri-1 & 8.34 & 64.2 & 10.83 & 1.26 & 0.38 & 0.99 & 13.45 & 1.14 & 297. & 313 & 239 & 151 \\
\hline Thanhtri-2 & 8.42 & 95.8 & 10.13 & 1.16 & 0.29 & 0.74 & 12.32 & 1.09 & 164 & 262 & 245 & 329 \\
\hline Gialam & 7.51 & 51.2 & 4.91 & 0.97 & 0.22 & 0.37 & 6.47 & 0.67 & 219 & 89 & 646 & 45 \\
\hline
\end{tabular}




\section{Experimental methods}

The soil samples were air dried, ground to pass through a 2-mm sieve, homogenized and stored in polyethylene containers. The soil $\mathrm{pH}\left(\mathrm{H}_{2} \mathrm{O}\right)$ was measured at a soil to water ratio of $1: 2.5(\mathrm{~kg} / \mathrm{L})$ with a glass electrode. Exchangeable cations were extracted with $1 \mathrm{~mol} \mathrm{~L} \mathrm{~L}^{-1}$ ammonium acetate solution following the method described by Wada and Umegaki (2001). Total cadmium was determined with the method developed by Asami and Kato (1977) but after a preliminary digestion of the soil samples with $7 \% \mathrm{H}_{2} \mathrm{O}_{2}$ to remove the humic substance. The atomic absorption spectroscopy was used to determine $\mathrm{Cd}$ and exchangeable cations. Total organic carbon was analyzed by Shimadzu TOC-5000A dissolved carbon analyzer. Particle size distribution was determined by sieving and pipette method after removing organic matter with $30 \% \mathrm{H}_{2} \mathrm{O}_{2}$ and dispersion by sonication. The clay fraction $(<2 \mu \mathrm{m})$ was separated from the silt and sand fractions following the method described by Hai et al: (2002). The mineralogy of sand, silt and clay fractions was analyzed by X-ray diffraction (XRD) with Ni-filtered $\mathrm{Cu} \mathrm{K}_{\alpha}$ radiation at a scanning speed of $2^{\circ} \mathrm{min}^{-1}$ over a $2 \theta$ range of 3 to $30^{\circ}$. The XRD analyses were made on air-dried and glycerol-solvated specimens for the $\mathrm{Mg}$-saturated clays and on air-dried and heated (at $300^{\circ} \mathrm{C}$ and at $550^{\circ} \mathrm{C}$ for $2 \mathrm{~h}$ ) specimens for the $\mathrm{K}$-saturated clays (Hai et al., 2002).

To characterize the lability of $\mathrm{Cd}$, the soil samples were extracted successively with water, $0.01 \mathrm{~mol} \mathrm{~L}^{-1} \cdot \mathrm{CaCl}_{2}, 0.1 \mathrm{~mol} \mathrm{~L}^{-1} \mathrm{HCl}$ and hot $6 \mathrm{~mol} \mathrm{~L}^{-1} \mathrm{HCl}$. A two gram portion of each soil sample and $20 \mathrm{~mL}$ of water were placed in a $85-\mathrm{mL}$ polycarbonate centrifuge tube and shaken on a reciprocal shaker for $2 \mathrm{~h}$. The tube was centrifuged and the extract was collected in a polyethylene bottle after filtration. In a similar way, residual soil was extracted successively with $20 \mathrm{~mL}$ of $0.01 \mathrm{~mol} \mathrm{~L}^{-1} \mathrm{CaCl}_{2}$ for $1 \mathrm{~h}$ and $0.1 \mathrm{~mol} \mathrm{~L}^{-1} \mathrm{HCl}$ for $1 \mathrm{~h}$. The $\mathrm{HCl}$ extraction is a modification of the method proposed by Marten, (1968), which was developed for extracting $\mathrm{Cu}, \mathrm{Zn}$ in contaminated soils. The shaking time was determined after preliminary experiments. After each extraction, the soil samples were rinsed with $10 \mathrm{~mL}$ of water by shaking and centrifugation and the supernatant was combined with the extract. All the experiments were carried out in triplicate and the results were averaged.

Finally the residual soil sample after the $\mathrm{HCl}$ extraction was transferred to a polytetrafluoroethylene beaker and digested with hot $6 \mathrm{~mol} \mathrm{~L}^{-1} \mathrm{HCl}$ following the procedure of Asami and Kato (1977).

The extracts were stored in polyethylene bottles with fitted stoppers at $4^{\circ} \mathrm{C}$ before analysis. The Cd concentration in the extract was analyzed by atomic absorption spectroscopy after adjusting background $\mathrm{HNO}_{3}$ concentration to $0.1 \mathrm{~mol} \mathrm{~L}^{-1}$.

\section{RESULTS AND DISCUSSION}

The basic soil properties of Vietnamese and Japanese soil samples were shown in Table 1. The soil pH ranged from 5.5 to 8.4 and the total organic carbon content was in a range from about 27 to $106 \mathrm{~g} \mathrm{~kg}^{-1}$. The lowest effective cation exchange capacity, i. e. the summed amount of exchangeable cations, was about $2.61 \mathrm{cmol}_{\mathrm{c}} \mathrm{kg}^{-1}$ for the Donganh1 sample and $13.45 \mathrm{cmol}_{\mathrm{c}} \mathrm{kg}^{-1}$ for the Thanhtril sample. The range of clay content was also wide, from 85.5 to $316.2 \mathrm{~g} \mathrm{~kg}^{-1}$. As arable soil, the selected soil samples are quite diverse 
in terms of the selected properties.

The total Cd content ranged from $0.67 \mathrm{mg} \mathrm{kg}^{-1}$ for the Gialam sample to $16.27 \mathrm{mg} \mathrm{kg}^{-1}$ for the Omuta-1 sample. The average Cd contents of the earth crust and soil are 0.1 and $0.35 \mathrm{mg} \mathrm{kg}^{-1}$, respectively (Sposito, 1984). Table 1 shows the Cd contents of the used soil samples were well above the averages for soil and earth crust. In general, the Cd content of the Japanese soil samples is significantly higher than that of Vietnamese soil samples. All the Japanese soil samples that were used in the present study were polluted with Cd through mining and smelting activities. Huy and Wada (2004) reported that the major sources of $\mathrm{Cd}$ in the Vietnamese soils were irrigation water and irrigation canal sediment that were polluted by $\mathrm{Cd}$-containing wastes from factories. In Japanese soils the major chemical forms of Cd that reached soils would have been soluble Cd-salts, particulates of sulfides. And so would have been in Vietnamese soils. The significant difference in the total Cd content between Japanese and Vietnamese soil samples would simply be due to difference in the amount of Cd-compounds that were incorporated in the soils (Nguyen, 2002).

The X-ray diffraction (XRD) patterns of representative soil samples are shown in Fig. 1 , in which the diffractograms are arranged from upper to lower in the following order; $\mathrm{Mg}$-saturated and air-dried, $\mathrm{Mg}$-saturated and glycerol solvated, $\mathrm{K}$-saturated and air-dried, K-saturated and heated at $300^{\circ} \mathrm{C}, \mathrm{K}$-saturated and heated at $550^{\circ} \mathrm{C}$. Numbers indicated at peaks are $\mathrm{d}$-spacings in nm. The diffraction patterns of the Omuta-2 sample resembled those of Omuta-1sample, the Dongganh-1 and Donganh-2 samples resembled the Donganh-3 sample, the Thanhtri-2 and Gialam samples resembled the Thanhtri-1 samples.

Since the amount of clay samples mounted on the glass slide was approximately the same, the peak intensity in the diffraction patterns may be a measure of the content of crystalline clay minerals. Among the 11 soil samples the heights of peaks in the Kyowa and Kadzuno samples, partiluclarly in the Kyowa sample, were apparently lower than those of any other soil, suggesting that the content of noncrystalline components is higher in these soil samples. These soil samples showed diffraction peaks at $1.4,1.0$ and $0.7 \mathrm{~nm}$ irrespective of the treatment and the peak intensity at $0.7 \mathrm{~nm}$ decreased significantly after heating at $550^{\circ} \mathrm{C}$. In addition the 1.4 and 1.0 peaks poorly resolved and the $1.0 \mathrm{~nm}$ peak intensified after $550^{\circ} \mathrm{C}$ heating with diminish of the peak at $1.4 \mathrm{~nm}$. These characteristics show that the major layer silicate minerals in these soils are vermiculite-chlorite intergrade, illite, kaolin minerals and some chlorite.

On the contrary, the diffraction peaks of the Hakuba sample were the sharpest. It exhibited strong peaks at $1.4,0.94,0.7 \mathrm{~nm}$, with an accessory peak at $1.0 \mathrm{~nm}$. For this sample, the intensity of the peaks at 1.4 and $0.7 \mathrm{~nm}$ did not change significantly, suggesting that the major clay minerals are chlorite. The characteristic peak at $0.94 \mathrm{~nm}$ indicates the presence of talc.

The Omuta-1 sample also showed peaks at 1.0 and $0.7 \mathrm{~nm}$ and the $0.7 \mathrm{~nm}$ peak diminished significantly after $550^{\circ} \mathrm{C}$ heating. The $1.4 \mathrm{~nm}$ peak in $\mathrm{Mg}$-saturated and air-dried specimen almost completely shifted to $1.7 \mathrm{~nm}$. These indicate that the major layer silicate minerals in the Omuta-1 sample are smectite, illite and kaolin minerals with small amount of chlorite.

The major layer silicate clay minerals are illite, kaolin minerals and some chlorite for 

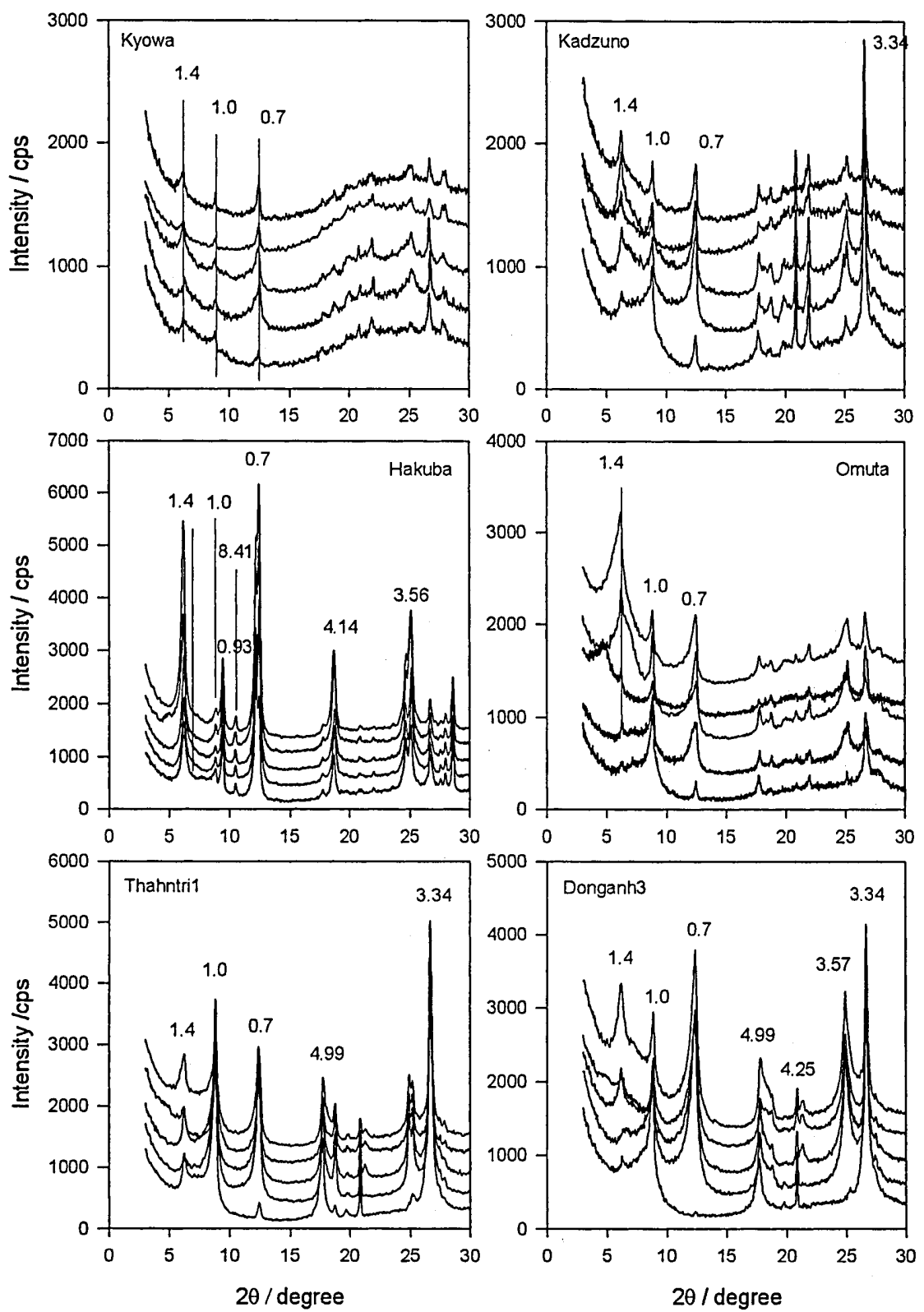

Fig. 1. X-ray diffractograms of clay fraction of sample soils. 
Table 2. Summury of mineralogical analyses.

\begin{tabular}{llc}
\hline Soil sample & \multicolumn{1}{c}{ Layer silicate minerals } & $\begin{array}{c}\text { Active iron } \\
\text { content / } \\
\mathrm{g} \mathrm{kg}^{-1}\end{array}$ \\
\hline Omuta-1 & Smectite, Kaolin, Illite, chlorites & 4.11 \\
Omuta-2 & Smectite, Kaolin, Illite, chlorites & 4.40 \\
Hakuba & Chlorite, Talc & 2.58 \\
Kyowa & Vermiculite-chlorite intergrade, lllite, Kaolin & 6.95 \\
Kadzuno & vermiculite-chlorite intergrade, illite, kaolin & 2.12 \\
Donganh-1 & Kaolin, Illite and Vermiculite-chlorite intergrade & 0.92 \\
Donganh-2 & Kaolin, Illite and Vermiculite-chlorite intergrade & 4.58 \\
Donganh-3 & Kaolin, Illite and Vermiculite-chlorite intergrade & 2.73 \\
Thanhtri-1 & Illite, Kaolin,Chlorite & 4.06 \\
Thanhtri-2 & Illite, Kaolin,Chlorite & 4.26 \\
Gialam & Illite, Kaolin,Chlorite & 17.05 \\
\hline
\end{tabular}

Thanhtri-1 sample, and kaolin mineral, illite and vermiculite-chlorite intergrade for Donganh-3.

The results of the XRD analysis were summarized in Table 2. In addition to the layer silicate clay minerals, most of the samples contained quartz and feldspars, but they are omitted from Table 1 because they are inert with regard to Cd adsorption. Mineralogy of silt and sand fraction was also examined by X-ray diffraction. The major minerals in these fractions were feldspars and quartz and there was no distinctive characteristics. Table 2 also lists the contents of noncrystalline iron oxides and hydroxides that was determined by oxalate-oxalic acid extraction.

The results of the sequential extraction were tabulated in Table 3. The sum of the successively extracted amounts of Cd was fairly close to the amount of total Cd for all soil samples (Table 1), indicating that the magnitude of the experimental errors involved in the multi-step extraction procedure is not serious. On the basis of the data in Table 3, percentage of each fraction was calculated and graphed in Fig. 2. Table 3 and Fig. 2 clearly show that there is a big difference in the lability of Cd between Japanese and Vietnamese soil samples. The percentage of the $0.0 \mathrm{molL}^{-1} \mathrm{CaCl}_{2}$ extractable fraction is in a range from about $2 \%$ to $7 \%$ for the Vietnamese samples whereas it is from $17 \%$ to $38 \%$ for the Japanese samples. The trend is quite opposite for the $6 \mathrm{~mol} \mathrm{~L}^{-1} \mathrm{HCl}$ extractable fraction and its percentage was from $53 \%$ to $86 \%$ for Vietnamese soils and from 8 to $7 \%$ for Japanese soil samples. The amount of water-extractable fraction was negligibly low for all soil samples except for the Omuta-1 sample.

The interpretation of the form of the water-extractable $\mathrm{Cd}$ is straightforward, whereas it is difficult to relate the $\mathrm{CaCl}_{2}$ and $\mathrm{HCl}$ extractable $\mathrm{Cd}$ to specific chemical forms. Generally, heavy metal cations that can be extracted with neutral salt solutions are labeled as exchangeable cations (Tessier et al., 1979). And those extractable in dilute acid are categorized as cations that are surface complexed on oxide minerals. However, recent studies indicated that at least a part of $\mathrm{Cd}$ ions that are released from cation exchange site by neutral salts are re-adsorbed on co-existing oxide minerals (Kheboian and Bauer, 1987). Thus, the Cd found in neutral salt extracts is actually a fraction of 


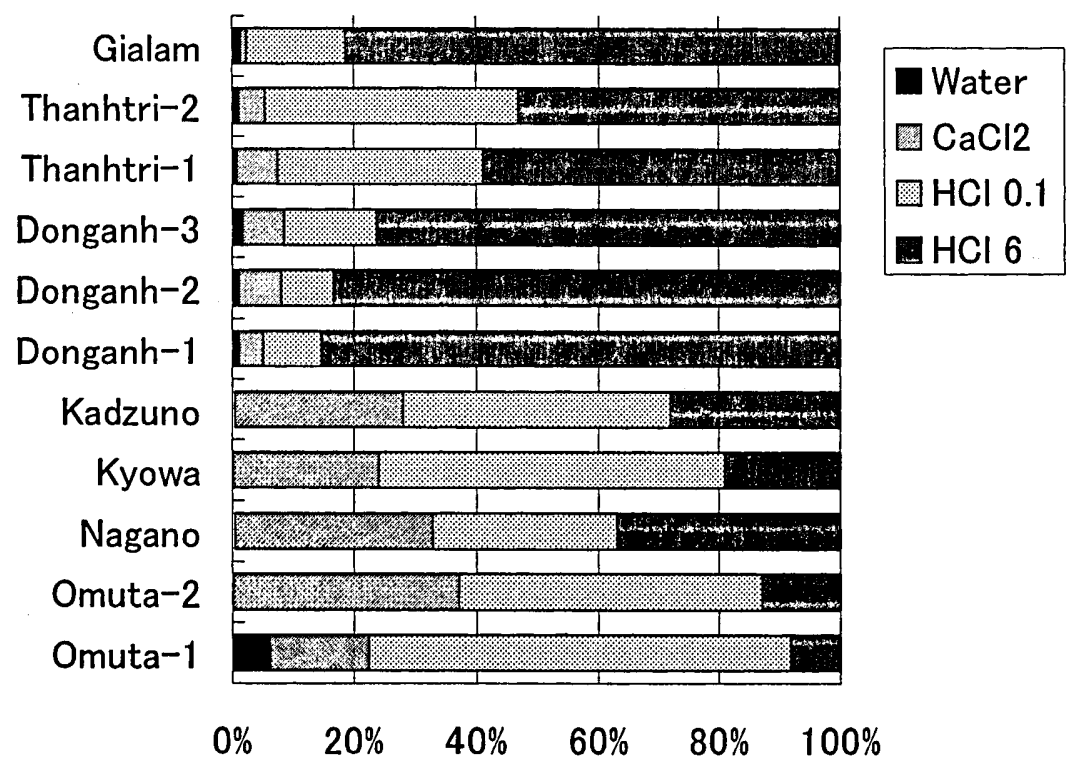

Fig. 2. Distribution of water-, $0.01 \mathrm{~mol} \mathrm{~L}^{-1} \mathrm{CaCl} 2-, 0.1 \mathrm{~mol} \mathrm{~L}^{-1} \mathrm{HCl}-$ and $6 \mathrm{~mol} \mathrm{~L}^{-1}$ $\mathrm{HCl}$-extractable $\mathrm{Cd}$ in sample soils.

Table 3. Results of sequential extraction.

\begin{tabular}{lccccc}
\hline & \multicolumn{5}{c}{ Cd ectrated by } \\
\cline { 2 - 5 } Sample & Water & $\begin{array}{c}0.01 \mathrm{~mol} \mathrm{~L}^{-1} \\
\mathrm{CaCl}_{2}\end{array}$ & $\begin{array}{c}0.1 \mathrm{~mol} \mathrm{~L} \mathrm{H}^{-1} \\
\mathrm{HCl}\end{array}$ & $\begin{array}{c}6 \mathrm{~mol} \mathrm{~L}^{-1} \\
\mathrm{HCl}\end{array}$ & Total \\
\cline { 2 - 5 } Omuta1 & 0.95 & 2.51 & 10.68 & 1.25 & 15.39 \\
Omuta2 & $<0.01$ & 2.96 & 3.95 & 1.03 & 7.67 \\
Nagano & $<0.01$ & 1.17 & 1.08 & 1.32 & 3.57 \\
Kyowa & $<0.01$ & 1.53 & 3.68 & 1.21 & 6.42 \\
Kadzuno & $<0.01$ & 1.08 & 1.70 & 1.09 & 3.87 \\
Donganh1 & $<0.01$ & 0.05 & 0.11 & 0.99 & 1.15 \\
Donganh2 & $<0.01$ & 0.07 & 0.08 & 0.81 & 0.96 \\
Donganh3 & $<0.01$ & 0.04 & 0.09 & 0.45 & 0.58 \\
Thanhtri1 & $<0.01$ & 0.10 & 0.50 & 0.88 & 1.48 \\
Thanhtri2 & $<0.01$ & 0.05 & 0.45 & 0.58 & 1.08 \\
Gialam & $<0.01$ & 0.01 & 0.13 & 0.65 & 0.79 \\
\hline
\end{tabular}

exchangeable Cd retained on permanent negative charges on layer silicate minerals. Similarly the Cd extracted by dilute acid from specifically adsorbing sites on oxide minerals is partly held on layer silicate minerals (Mori and Wada, 2003). Therefore, complete speciation of heavy metals in soils by successive extraction is in a sense an illusion.

The sequential extraction procedure employed in the present study does not aim at chemical speciation of $\mathrm{Cd}$ in the soil samples. Extracting solutions and extraction condi- 

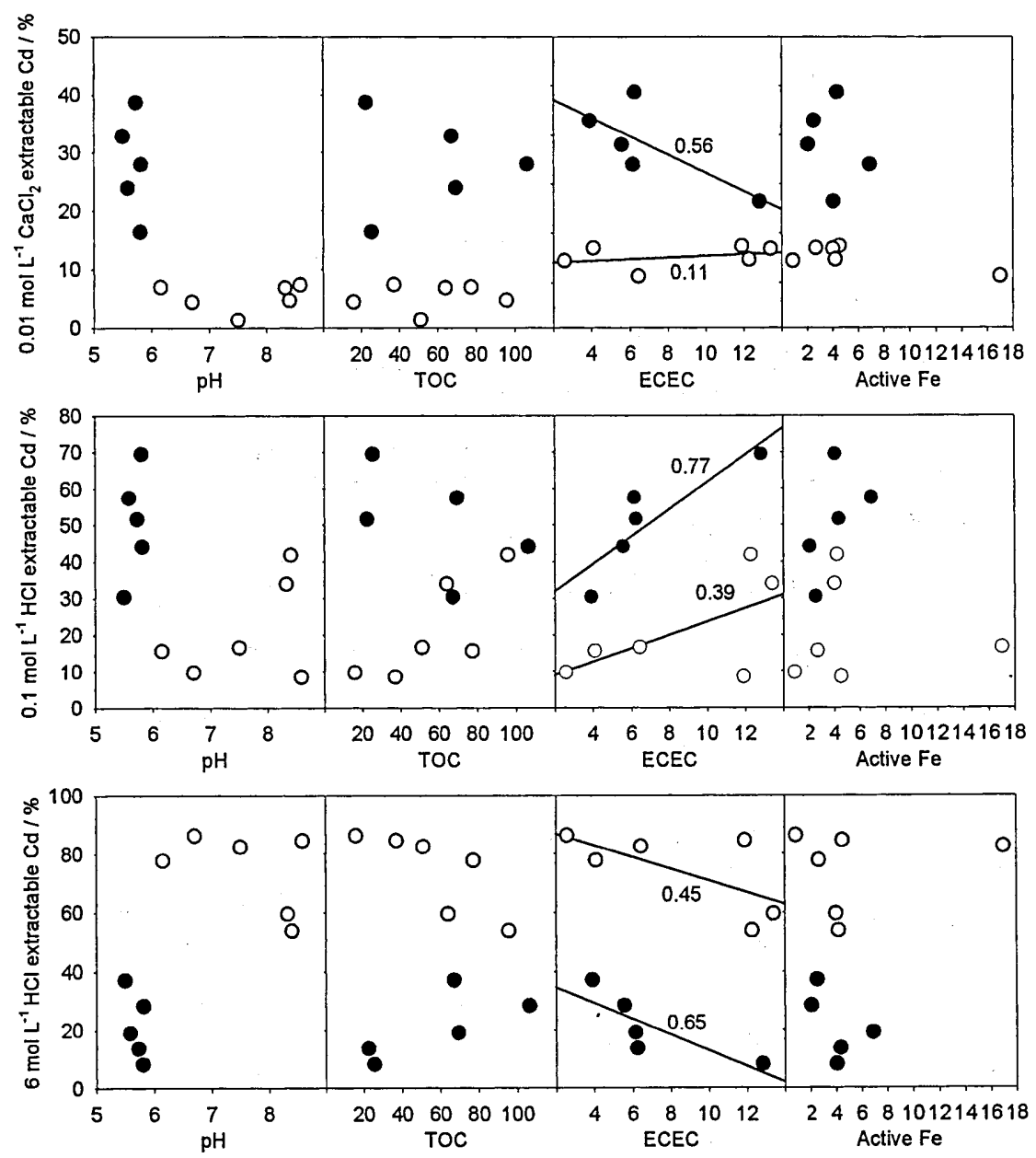

Fig. 3. Pair-wise scatter plot among fractions of three forms of $\mathrm{Cd}$ and $\mathrm{pH}$, Organic carbon content (TOC), effective cation exchange capacity (ECEC) and oxalate soluble $\mathrm{Fe}$ (Active $\mathrm{Fe}$ ).

tions are selected to obtain a measure of lability of $\mathrm{Cd}$ under different chemical conditions. The $0.01 \mathrm{~mol} \mathrm{~L}^{-1} \mathrm{CaCl}_{2}$ solution has an ionic strength that is prevailing in many arable soils during plant growth. The $0.01 \mathrm{~mol} \mathrm{~L}^{-1} \mathrm{CaCl}_{2}$ extractable Cd can be regarded as a measure of lability of Cd under normal soil conditions (Houba et al., 1990). With regard to $\mathrm{Cd}$, the $0.1 \mathrm{~mol} \mathrm{~L}^{-1} \mathrm{HCl}$ is strong enough for quantitative extraction of both the exchangeable and surface complexed $\mathrm{Cd}$ (Mori and Wada, 2003) and this fraction would be a measure of $\mathrm{Cd}$ susceptible to soil acidification. And it would be reasonable to regard the hot $6 \mathrm{~mol} \mathrm{~L}^{-1} \mathrm{HCl}$ extractable fraction as non-labile $\mathrm{Cd}$ in soils.

The percentage of each $\mathrm{Cd}$ fraction was plotted against measured values of chemical 
and mineralogical properties in Fig. 3. In this plot, the percentages were used as dependent variables because the absolute amount of $\mathrm{Cd}$ in soils depends mostly on anthropogenic factors, not on nature of soils. Here, again, there is a big difference in trends between the Japanese and Vietnamese soil samples. As a whole the percentages of three $\mathrm{Cd}$ fractions seems rather indifferent to the selected soil properties except for to the ECEC and soil $\mathrm{pH}$.

Due to the limited sample size it is difficult to generalize but the relationships between percentages of three Cd fractions and ECEC seems meaningful particularly for the Japanese soil samples. The percentage of the $6 \mathrm{~mol} \mathrm{~L}^{-1} \mathrm{HCl}$ extractable $\mathrm{Cd}$ decreased as the ECEC increased (Fig. 3). This suggests that more $\mathrm{Cd}$ is distributed over cation exchange sites on layer silicate minerals as ECEC increases. The percentage of the $0.01 \mathrm{~mol} \mathrm{~L}^{-1} \mathrm{CaCl}_{2}$ extractable $\mathrm{Cd}$ was also negatively correlated with ECEC for the Japanese soils. Although these trends are confusing, they are reasonable because the $0.01 \mathrm{~mol} \mathrm{~L}^{-1} \mathrm{CaCl}_{2}$ solution extract only a part of the exchangeable $\mathrm{Cd}$ at the present soil : solution ratio and its extent is expected to inversely correlate with the ECEC. The positive correlation between the percentage of the $0.1 \mathrm{~mol} \mathrm{~L}^{-1} \mathrm{HCl}$ extractable $\mathrm{Cd}$ and the ECEC is also understandable because $0.1 \mathrm{~mol} \mathrm{~L}^{-1}$ of strong acid extracts most part of both the exchangeable and surface complexed Cd (Mori and Wada, 2003).

As already discussed above, the Vietnamese soil samples contained vermiculite-chlorite intergrades. Saha et al. (2001) synthesized a hydroxyaluminum-montmorillonite complex and carried out a series of heavy metal adsorption experiments. According to their data, the adsorption percentage for $\mathrm{Cd}$ increased as solution $\mathrm{pH}$ increased and reached $100 \%$ at around $\mathrm{pH} 7$ and the adsorbed $\mathrm{Cd}$ was not extracted by washing with a $0.01 \mathrm{~mol} \mathrm{NaClO}_{4}$ solution. The low percentage of the $0.01 \mathrm{~mol} \mathrm{CaCl}_{2}$ extractable $\mathrm{Cd}$ in the Vietnamese soil samples may partly due to the adsorption onto the hydroxyaluminum interlayer of the vermiculite-chlorite intergrades.

\section{CONCLUSIONS}

The total Cd content was about 3 to $16 \mathrm{mg} \mathrm{kg}^{-1}$ for the Japanese samples and 0.5 to $1.1 \mathrm{mg} \mathrm{kg}^{-1}$ for Vietnamese samples and the extent of pollution is much less in the Vietnamese soils examined. There was also a big difference between the Japanese and Vietnamese soil samples with regard to the extractability of $\mathrm{Cd}$ in $0.01 \mathrm{~mol} \mathrm{~L}^{-1} \mathrm{CaCl}_{2}$ and 0.1 and $6 \mathrm{~mol} \mathrm{~L}^{-1} \mathrm{HCl}$. More than $60 \%$ of the total $\mathrm{Cd}$ was extractable in $0.01 \mathrm{~mol} \mathrm{~L}^{-1} \mathrm{CaCl}_{2}$ and $0.1 \mathrm{~mol} \mathrm{~L}^{-1} \mathrm{HCl}$ for the Japanese soils, whereas the percentage of Cd that were extractable in these solution was below $50 \%$ for Vietnamese soils. This indicates that Cd in the Vietnamese soils is much less labile in normal and acidified soil conditions. Graphical analyses of the correlation among the extractability of $\mathrm{Cd}$ and soil properties including $\mathrm{pH}$, TOC and ECEC indicated that no single property governs the chemical forms and extractability. Contribution of hydroxyaluminum interlayer to the Cd adsorption was suggested but further mineralogical research is needed.

\section{ACKNOWLEDGMENT}

This study was supported in part by a Grant-in-Aid for Scientific Research from the 
Japanese Society of Promotion of Sciences (\# 14350259).

\section{REFERENCES}

Asami, T. and T. Kato 1977 Comparison of analytical methods for total cadmium, zinc, lead and copper in soils. Jpn. J. Soil Sci. Plant Nutr. 30: 2363-2375

Beckett P. H. T. 1989 The use of extractants in studies on trace metals in soils, sewage sludges, and sludge-treated soils. Adv. Soil Sci. 9: 144-176

Hai, D. N., T, -Q. Huy and K. Egashira 2002 Mineralogy and clay degradation in grey degraded soils of Vietnam. Clay Sci. 11: 535-547

Haq, A. U., T. E. Bates and Y. K. Soon 1980 Comparison of extractants for plant-available zinc, cadmium, nickel, and copper in contaminated soils. Soil. Sci. Soc. Am. J. 44: 772-777

Houba, V. J. D., I. Novozamsky, Th. M. Lexmond and J. J. van der Lee 1990 Applicability of $0.01 \mathrm{M} \mathrm{CaCl}_{2}$ as a single extraction solution for the assessment of the nutrient status of soils and other diagnostic purposes. Commun. Soil Sci. Plant Anal. 21: 2281-2290

Huy, T. -Q. and S. -I. Wada 2004 Cadmium status of some soils and sewage sludge in Red River delta of Vietnam. J. Fac. Agr. Kyuhsu Univ., 49: 149-155

Kheboian, C. and C. F. Bauer 1987 Accuracy of selective extraction procedures for metal speciation in model aquatic sediments. Anal Chem. 59: 1417-1423.

Lindsay, W. L. and W. A. Norwell 1978 Development of a DTPA soil test for zinc, iron, manganese, and copper. Soil Sci. Soc. Am. J. 42: 421-428

Martens, D. C. 1968 Plant availability of extractable boron, copper, and zinc as related to selected soil properties. Soil Sci. 106: $23-28$

Mehlich, A. 1984 Mehlich No 3 soil test extractant: A modification of Mehlich No 2. extractant. Commun. Soil Sci. Plant Anal. 15: 1409-1416

Mori, Y. and S. -I. Wada 2003 Acid dissolution properties of cadmium in polluted smectitic paddy soil. $J$. Clay Sci. Soc. Jpn. 41: 196-201. (in Japanese)

Nguyen. 2002 The evaluation of $\mathrm{Pb}, \mathrm{Cd}, \mathrm{Hg}$, As and pesticide residual content in soil of Gialam, Donganh, Thanhtri district. Report on environmental protection project. Ministry of science, technology and environment 2002

Saha, U. K., S. TaniguchiK. and K. Sakurai 2001 Adsorption Behavior of Cadmium, Zinc, and Lead on Hydroxyaluminum- and Hydroxyaluminosilicate-Montmorillonite Complexes. Soil Sci. Soc. Am. J. 65: 694-703

Ross, S. M. 1994 Retention, transformation and mobility of toxic metals in soils. In "Toxic metals in soil-plant systems" by S. M. Ross, John Wiley \& Sons, New York, pp. 63-153

Singh, B.R. and R. P. Narwal 1984 Plant availability of heavy metals in sludge-treated soil. II. Metal extractability compared with plant metal uptake. J. Environ. Qual. 13: 344-349

Sposito, G. 1984 The Chemistry of Soils. Oxford University Press, New York

Tessier, A., P. G. C. Campbell and M. Bisson 1979 Sequential extraction procedure for the speciation of particulate trace metals. Anal. Chem. 51: 844-851

Wada, S. -I. and Y. Umegaki 2001 Major ion and electrical potential distribution in soil under electrokinetic remediation. Environ. Sci. Technol. 35: 2151-2155 